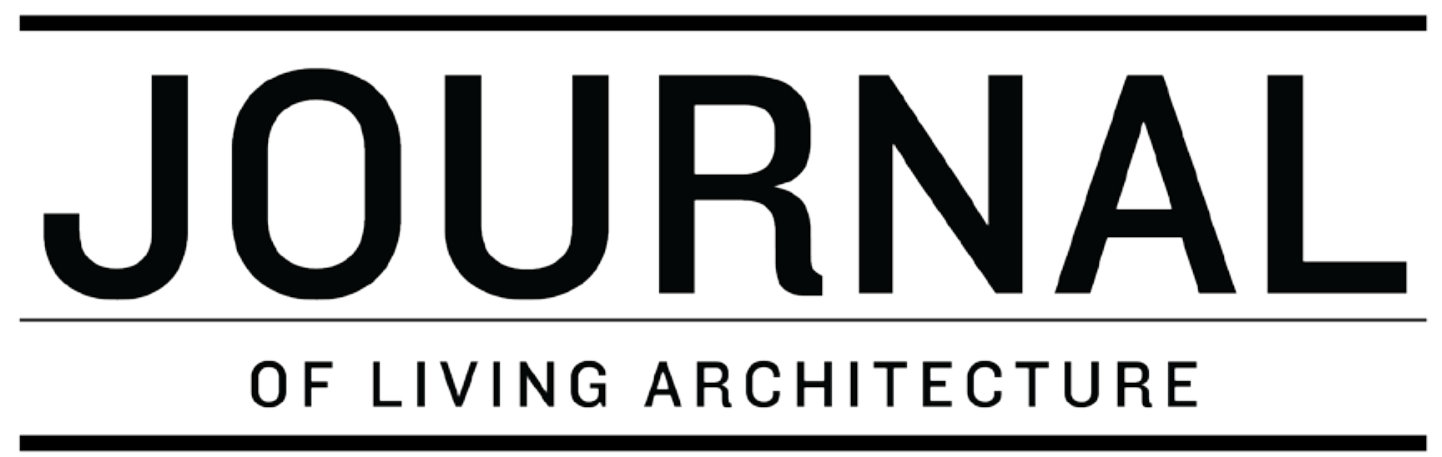

A GREEN INFRASTRUCTURE FOUNDATION PUBLICATION

Volume 4 Number 1 Pages 14-25

2017

\title{
Life Cycle Cost Analysis of Extensive Green Roofs in Switzerland and the Netherlands
}

\author{
Davis Kantor ${ }^{1}$ \\ Department of Facility Management in conjunction with the Green Roof CompetenceCenter, \\ Zürich University of Applied Sciences, Zürich, Switzerland
}

[This manuscript has been previously published as a conference paper

\begin{abstract}
Extensive green roofs in Switzerland and the Netherlands are economically sustainable when considering the added energy savings, municipal incentives and storm water fee reductions. By combing surveys, interviews, and reviews of municipal regulations for fifteen projects the Life Cycle Cost (LCC) was calculated by discounting green roof cash flows over a 50 year time period to determine a Net Present Value (NPV). This research finds that an extensive green roof NPV in Switzerland costs $27 \%$ - 37\% less than a conventional flat roof. Similarly in the Netherlands, the NPV of green roofs is determined to be $16 \%-26 \%$ less than a conventional flat roof. Presented here is summary of the results and the explanation of local influences of municipal incentives.
\end{abstract}

KEY WORDSextensive green roof, Net Present Value, Life Cycle Cost, planned preventative maintenance, Whole Life Cost

Please cite as: Kantor, Davis. 2017. Life Cycle Cost Analysis of Extensive Green Roofs in Switzerland and the Netherlands.Journal of Living Architecture.4(1): 14-25 


\section{INTRODUCTION}

Green roofs, as a biophilic design component, are economically evaluated and summarized in this research brief to better understand investment costs and benefits. The life cycle cost (LCC) economic analysis presented provides insight on today's cost associated with extensive green roofing systems in Switzerland and the Netherlands. Today, the green roof policies in German speaking cities of Switzerland aim to maximize native biodiversity whereas cities in the Netherlands do not have the same consistent goals and measures to incentivize green roof construction. Specifically, the municipality in Amsterdam promotes holistic sustainable benefits while the municipality in Rotterdam focuses on bringing an innovative approach to green roof design in order to maximize water storage benefits.

The aim of this research is to answer the question: How are green roofs defined as successful in Switzerland and the Netherlands and how can these successes be compared in terms of economic costs and benefits?

Thefindings provide investors in these locations with a realistic expectation for extensive green roof monetary costs. Green roof design guidelines are well established in European countries and it's important to examine this history so that future designers in the U.S.A have a well informed understanding on the composition and quality of green roofs. (Werthmann, 2007)The LCC of intensive green roofs is not evaluated in this research due to a lack of samples and pricing transparency with intensive green roof material providers.

\section{LIFE CYCLE COSTING}

Similar to the report done by the United States General Services Administration (2011) the green roof cash flow considerations from urban agriculture, acoustic insulation, job generation and increased productivity are not accounted for in the NPV calculation presented here. These benefits are directly related to social and environmental benefits and must remain an important consideration for investors due to their affect on employee wellbeing and corporate image, both of which contribute to overall corporate sustainability. In particular, the field of health care has increasing scientific studies focusing on affective biophilic design for health outcomes and stress. Several studies have found recovering hospital patients in rooms with a view of nature have the ability to substantially alleviate pain (Ulrich, 2008). One significant pioneer project in Basel, Switzerland was the construction of additional clinics at the University of Hospital, all consisting of green roofs. The intent was to provide patients with a quality view of vegetation in order to benefit the recovery process (Brenneisen, 2010). Additionally, office workers that can view nature from their desk are reported to have less work related frustration, more enthusiasm for their job, higher life satisfaction and overall improved well-being(Kaplan, 1993).All these green roof benefits have direct cost saving implications but are not considered in the following LCC calculations.

This LCC study evaluates 15 green roofproject surveysin Switzerland and the Netherlands collected during 2014 (Table 1). To calculate the LCC of a green roof the additional monetary costs and savings of a green roof were calculated as a NPV by discounting cash flows of a green roof investment. The NPV calculation presented (Table 2) 
Table 1 Green roof survey questions

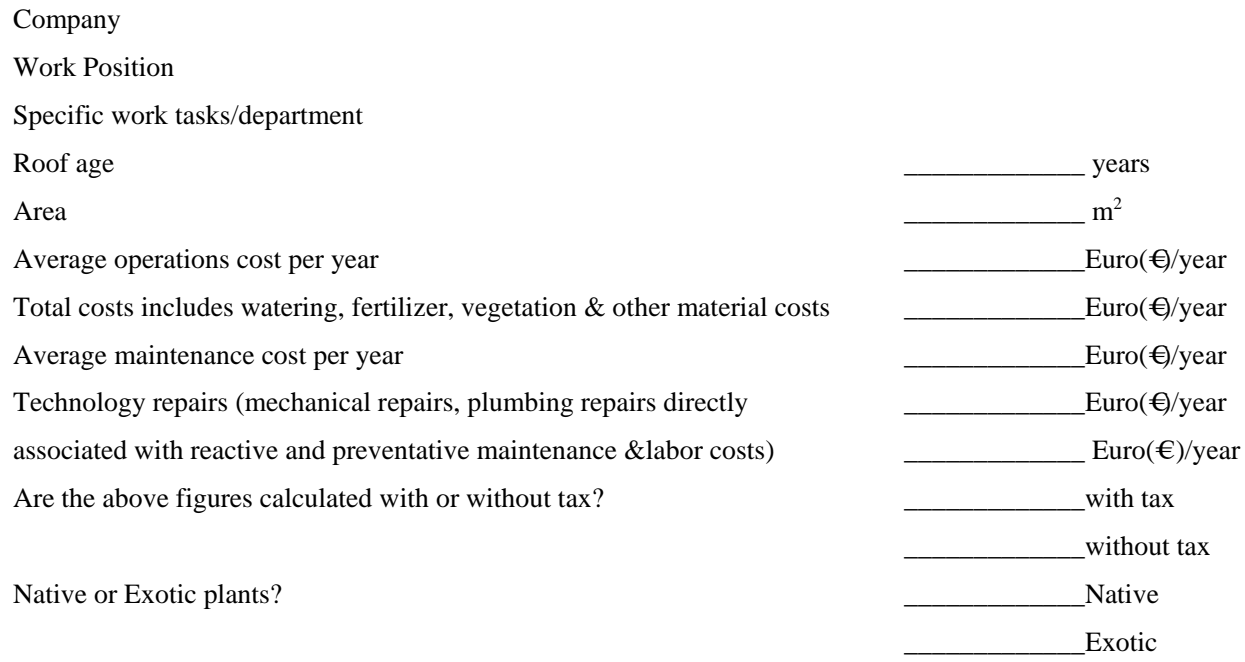

is an example LCC calculation tool for a single green roof sample.This LCC calculation toolcan be used for evaluating many different building component investment options and was used to evaluate the NPV of each green roof samplein this research. The sum of the discounted cash flow columns are independently divided by the roof area for a value directly comparable to the calculated NPV of all other green roofs in this study.If the NPV of a particular project is positive then theexpected cash flows will exceed the costs. Negative cash flows for a green roof include the additional cost of a green roof compared to a conventional flat black roof. The positive cash flows to consider in this calculation include cost savings when compared to a conventional roof, which include reduced energy consumption, storm water fee reductions and municipal subsidies. In addition to a comprehensive literature review, the author conducted informal conversational interviews with industry professionals and municipal government agents in Switzerland and the Netherlands to determine specific green roof cost savings.

Investment decisions in engineering systems are not based on initial costs but rather the sum of costs throughout the product life cycle (e.g. operation, maintenance, logistics, etc.). Life cycle costing is a cost estimation and comparison method used to assess alternative investments by considering the entire life cycle of systems. LCC applications are widespread and unstandardized due to the complexity of industrial systems. There are many different life cycle costing models used to estimate investment opportunities of all types ranging from building components to industrial system research and development strategies. Regardless of the LCC model chosen, it must be as accurate as possible or otherwise may lead to serious budget implications (Dhillon, 2010).One aim of LCC for real estate construction is to influence investments in order to reduce future operational costs. LCC is a tool for evaluating the monetary costs and benefits of a building or building component but does not consider environmental or social costs. The NPV calculation presented in this research is only one piece to the puzzle of a complete LCC methodology. Life cycle costing for a building makes it possible to gain a complete and comparable economical evaluation for different building designs. The LCC tool developed by theInternational Facilities Management Association (IFMA) Switzerland is a comprehensive investment tool that considers all elements of a 
Table 2 Example Calculation of Life Cycle Costing Net Present Value for one green roof $\left(420 \mathrm{~m}^{2}\right)$

\begin{tabular}{|c|c|c|c|c|c|c|c|c|}
\hline Year & $\begin{array}{c}\text { Initial } \\
\text { Cost }\end{array}$ & Subsidy & Repair & Maintenance & $\begin{array}{l}\text { Energy } \\
\text { Saving }\end{array}$ & $\begin{array}{l}\text { Discount } \\
\text { Factor }\end{array}$ & $\begin{array}{l}\text { No Energy } \\
\text { Savings } \\
\text { Discounted } \\
\text { Cash Flow }\end{array}$ & $\begin{array}{l}\text { Disc.Cash Flow } \\
\text { Incl. Energy } \\
\text { Savings }\end{array}$ \\
\hline & $-13,000$ & 12,600 & 0 & 0 & 0 & 1 & -4 & -400 \\
\hline 1 & & & -400 & -700 & 281.4 & 0.917485063 & -1053.6398 & -784.0996169 \\
\hline 2 & & & -400 & -700 & 281.4 & 0.87881711 & -1009.233 & -751.0532729 \\
\hline 3 & & & -400 & -700 & 281.4 & 0.841778841 & -966.69882 & -719.3996866 \\
\hline 4 & & & -400 & -700 & 281.4 & 0.806301572 & -925.95672 & -689.0801596 \\
\hline 5 & & & -400 & -700 & 281.4 & 0.806301572 & -886.93172 & -660.0384671 \\
\hline 6 & & & -400 & -700 & 281.4 & 0.772319514 & -849.5514 & -632.2207539 \\
\hline 7 & & & -400 & -700 & 281.4 & 0.739769649 & -813.7466 & -605.5754348 \\
\hline 8 & & & -400 & -700 & 281.4 & 0.708591618 & -779.45077 & -580.0530984 \\
\hline 9 & & & -400 & -700 & 281.4 & 0.678727603 & -746.60036 & -555.6064161 \\
\hline 10 & & & -400 & -700 & 281.4 & 0.650122225 & -715.1344 & -532.1900538 \\
\hline 11 & & & -400 & -700 & 281.4 & 0.622722438 & -684.9946 & -509.7605879 \\
\hline 12 & & & -400 & -700 & 281.4 & 0.596477431 & -656.12517 & -488.2764252 \\
\hline 13 & & & -400 & -700 & 281.4 & 0.571338536 & -628.47238 & -467.6977253 \\
\hline 14 & & & -400 & -700 & 281.4 & 0.547259134 & -601.98504 & -447.9863269 \\
\hline 15 & & & -400 & -700 & 281.4 & 0.524194573 & -576.61402 & -429.1056771 \\
\hline 16 & & & -400 & -700 & 281.4 & 0.502102081 & -552.31228 & -411.0207635 \\
\hline 17 & & & -400 & -700 & 281.4 & 0.480940691 & -529.03475 & -393.6980493 \\
\hline 18 & & & -400 & -700 & 281.4 & 0.46067116 & -506.73827 & -377.1054112 \\
\hline 19 & & & -400 & -700 & 281.4 & 0.4412559 & -485.38149 & -361.2120797 \\
\hline 20 & & & -400 & -700 & 281.4 & 0.422658908 & -464.92479 & -345.9885821 \\
\hline 21 & & & -400 & -700 & 281.4 & 0.404845697 & -445.33026 & -331.4066879 \\
\hline 22 & & & -400 & -700 & 281.4 & 0.387783235 & -426.56155 & -317.4393562 \\
\hline 23 & & & -400 & -700 & 281.4 & 0.37143988 & -408.58386 & -304.060686 \\
\hline 24 & & & -400 & -700 & 281.4 & 0.355785326 & -391.36385 & -291.2458678 \\
\hline 25 & & & -400 & -700 & 281.4 & 0.340790542 & -374.86959 & -278.9711378 \\
\hline 26 & & & -400 & -700 & 281.4 & 0.326427722 & -359.07049 & -267.2137335 \\
\hline 27 & & & -400 & -700 & 281.4 & 0.312670232 & -343.93725 & -255.951852 \\
\hline 28 & & & -400 & -700 & 281.4 & 0.299492559 & -329.44181 & -245.1646092 \\
\hline 29 & & & -400 & -700 & 281.4 & 0.286870268 & -315.55729 & -234.8320011 \\
\hline 30 & & & -400 & -700 & 281.4 & 0.27477995 & -302.25794 & -224.934867 \\
\hline 31 & & & -400 & -700 & 281.4 & 0.263199186 & -289.5191 & -215.4548534 \\
\hline 32 & & & -400 & -700 & 281.4 & 0.2521065 & -277.31714 & -206.3743807 \\
\hline 33 & & & -400 & -700 & 281.4 & 0.241481322 & -265.62945 & -197.6766099 \\
\hline 34 & & & -400 & -700 & 281.4 & 0.186500737 & -205.15081 & -152.6695032 \\
\hline 35 & & & -400 & -700 & 281.4 & 0.221555506 & -243.71105 & -181.3653369 \\
\hline 36 & & & -400 & -700 & 281.4 & 0.212217917 & -233.4397 & -173.7215871 \\
\hline 37 & & & -400 & -700 & 281.4 & 0.203273867 & -223.60125 & -166.3999876 \\
\hline 38 & & & -400 & -700 & 281.4 & 0.194706769 & -214.17744 & -159.3869613 \\
\hline 39 & & & -400 & -700 & 281.4 & 0.186500737 & -205.15081 & -152.6695032 \\
\hline & -194544 & & -400 & -700 & 281.4 & 0.178640553 & -3671.8493 & -3621.579922 \\
\hline
\end{tabular}




\begin{tabular}{|c|c|c|c|c|c|c|c|c|}
\hline Year & $\begin{array}{c}\text { Initial } \\
\text { Cost }\end{array}$ & Subsidy & Repair & Maintenance & $\begin{array}{l}\text { Energy } \\
\text { Savings }\end{array}$ & $\begin{array}{c}\text { Discount } \\
\text { Factor }\end{array}$ & $\begin{array}{l}\text { No Energy } \\
\text { Savings Disc } \\
\text { Cash Flow }\end{array}$ & $\begin{array}{l}\text { Disc.Cash Flow } \\
\text { Incl. Energy } \\
\text { Savings }\end{array}$ \\
\hline 41 & & & -400 & -700 & 281.4 & 0.17111164 & -188.222804 & -140.0719888 \\
\hline 42 & & & -400 & -700 & 281.4 & 0.163900039 & -180.29004 & -134.1685716 \\
\hline 43 & & & -400 & -700 & 281.4 & 0.156992374 & -172.69161 & -128.5139575 \\
\hline 44 & & & -400 & -700 & 281.4 & 0.150375837 & -165.41342 & -123.0976605 \\
\hline 45 & & & & & & & & -117.9096365 \\
\hline 46 & & & -400 & -700 & 281.4 & 0.137967585 & -151.7643431 & -112.9402648 \\
\hline 47 & & & -400 & -700 & 281.4 & 0.132152859 & -145.3681448 & -108.1803303 \\
\hline 48 & & & -400 & -700 & 281.4 & 0.126583198 & -139.241518 & -103.621006 \\
\hline 49 & & & -400 & -700 & 281.4 & 0.121248274 & -133.3731015 & -99.25383717 \\
\hline \multirow[t]{6}{*}{50} & & & -400 & -700 & 281.4 & 0.116138194 & -127.7520129 & -95.07072526 \\
\hline & & & & & & & $\begin{array}{l}\text { No energy } \\
\text { savings }\end{array}$ & \\
\hline & & & & & & & Project NPV & 25971.88993 \\
\hline & & & & & & & Project NPV/ $\mathrm{m}^{2}$ & -61.83783316 \\
\hline & & & & & & & $\begin{array}{l}\text { Incl. energy } \\
\text { savings } \\
\text { Project NPV } \\
-20319.19192\end{array}$ & \\
\hline & & & & & & & Project NPV/ m² & -48.37902838 \\
\hline
\end{tabular}

building. This method for LCC calculations was developed by the IFMA Switzerland in conjunction with German Facility Management Association (GEFMA) and is based on international standards (ISO 15686-52008). By entering specific product information for a particular future building design, the tool will automatically calculate the total LCC of the building. A lower LCC indicates the preferred option for economic sustainability aspects of the building (Ulrich, 2008).

According to the Swiss Chapter of International Facilities Management Association(2011) the NPV method is a form of dynamic LCC analysis that accounts for the effects of time on money over the life cycle of a building or building component. A NPV is calculated by estimating all future cash flows of a particular project and is discounted back to a one single price relative to the present day using the present value formula. One way to think of the present value equation is to multiply the future cash flow by a discount rate and the NPV is then the sum of all present values over the time period in consideration. The resulting NPV calculations consider the additional cost premium of adding a green roof installation. This can be visualized as everything above the waterproofing because a conventional roof also consists of a waterproofing layer. Thus, the cash flows include installation costs (materials, labor, etc.), maintenance costs, repair costs, municipal subsidies, storm water tax fee reductions and energy savings.

Based on a similar study of green roofs by the United States General Services Administration (2011), the green roof NPV was calculated using a 4.4\% interest rate over a period of 50 years. A sensitivity analysis was considered by using two different energy savings estimations. This approach provided a range of values for the NPV estimate. For comparable figures between Holland and the Netherlands, all NPV figures are presented in 
Euro currencies. To convert the Swiss NPV figures from Swiss Francs (CHF) to Euros (€), the average of the currency exchange rates over the past 8 years is determined. A historical statistical record of currencies and average exchange rates are considered in the data analysis to account for fluctuations in the economy. Additionally, any increased materials cost due to the increased cost of goods and labor in Switzerland was accounted for in the NPV calculations.

\section{RESULTS}

\section{Construction Costs}

Many of the Switzerland survey respondents did not include initial construction costs. However, according to the SwissGreen Roof Manager Heinz Sigrist(2014) the estimation ranges below are used for determining the initial construction costs of green roofs in Switzerland in Swiss Francs (CHF). The average costs are as follows:

- Protection and/or drainage layers: $8.50 \mathrm{CHF} / \mathrm{m}^{2}$

- Substrate: $17.50 \mathrm{CHF} / \mathrm{m}^{2}$

- Seeds: $4.50 \mathrm{CHF} / \mathrm{m}^{2}$

- Maintenance work 1 time per year for first 3 years: $4 \mathrm{CHF} / \mathrm{m}^{2}$ (Sigrist, 2014)

The sum is $30.50 \mathrm{CHF} / \mathrm{m}^{2}$ for the initial construction materials costs and $4 \mathrm{CHF} / \mathrm{m}^{2}$ for the first 3 years; $34.50 \mathrm{CHF} / \mathrm{m}^{2}$ is also considered for the replacement cost at year 40 . The maintenance costs of $4 \mathrm{CHF} / \mathrm{m}^{2}$ to ensure $75 \%$ coverage in 2 years is not required, only recommended by the Swiss Professional Association of Building Greening (SFG). However, the maintenance cost component of $12 \mathrm{CHF} / \mathrm{m}^{2}$ for three years is included in the initial construction cost cash flow approximation to account for the initial construction labor costs. A total of $46.50 \mathrm{CHF} / \mathrm{m}^{2}$ was approximated for the initial construction costs of Switzerland survey respondents who didn't answer this particular question. The one respondent from Switzerland who answered the initial construction cost had installed a $400 \mathrm{~m}^{2}$ green roof for a total 20,000 CHF equaling $50 \mathrm{CHF} / \mathrm{m}^{2}$, which provides assurance that the estimation was approximately accurate.

The average decommissioning costs of the waterproofing layer at the end of its lifetime was $45 \mathrm{CHF} / \mathrm{m}^{2}$ and disposal costs to a special landfill equate to $250 \mathrm{CHF} / \mathrm{m}^{3}$. (Sigrist, 2014) This process was required for a typical roof as well and for proper comparison reasons the disposal and decommissioning costs were not included in any of the NPV calculations. Only the material costs of $34.50 \mathrm{CHF} / \mathrm{m}^{2}$ was considered for replacement in year 40 at the end of the green roof life cycle. Based on this analysis, the estimated replacement costs for green roofs in the Netherlands was done the same way by converting to the Euro and accounting for the exchange by an increase in labor unit costs for an approximate $46.32 € / \mathrm{m}^{2}$.

The specific economic green roof valuations for Switzerland and the Netherlands are detailed below. The exact monetary cost and benefit of green roofs varies depending on specific region and green roof design. For example, the energy saving benefit of green roofs is highly dependent on the climate, location, substrate thickness, vegetation type, utility rates, building age and whether or not the green roof is irrigated (Bass \& Sailor, 2014). Intensive 
green roofs were not evaluated in this research but do have a higher life cycle cost due to additional material quantities, maintenance requirements and structural implications.

Similar to the green roof LCC study by Carter and Keeler (2008) the cash flow analysis presented here considers a 40-year lifetime of a green roof. According to the United States General Services Administration (2011) the lifetime increase to 40 years for the waterproofing layer is the greatest cost saving factor of a green roof. Both locations, Netherland and Switzerland were assumed to have the same green roof lifetime expectancy of 40 years. Conventional flat roof skin has an expected lifetime of 25 years (CRB Schweizerische Zentralstelle für Baurationalisierung, 2012) and the conventional roof would be replaced two times in the corresponding 50-year LCC estimation for Switzerland and the Netherlands.

\section{Municipal Incentives}

One primary motivation for municipalities to incentivize green roof construction is storm water retention benefits. Rain that falls upon a conventional roof runs to the street and eventually enters the public sewer system. Rain that falls upon a green roof is absorbed by the vegetation and substrate. The storm water benefit of a green roof helps to alleviate the public sewer systems and effectively reduces replacement costs of public utilities. The exact storm water fee reductions are directly correlated with the size of the green roof and are credited to the green roof property on an annual basis. The Basel Water Protection Act took effect January 1, 2001 and reflects stormwater management charges to be paid by real estate property owners. The stormwater fees charge property owners to cover the state's cost for construction, operation, maintenance, and replacement of sewer systems. The fees include a cleaning fee (CHF $1.20 / \mathrm{m}^{3}$ ) for water discharged to the sewer and a drainage fee. The drainage fee is composed of two fees. One fee for the discharge of wastewater (CHF $0.75 / \mathrm{m}^{3}$ ) and one fee for the derivation of storm water (CHF $0.90 / \mathrm{m}^{2}$ ) include impervious property areas that divert rainwater runoff directly to the sewer. According to the Construction and Transport Department of the Canton of Basel (2012), vegetated roofs receive a 50\% reduction on the derivation of storm water fee meaning that green roof properties in Basel receive an annual savings of $0.45 \mathrm{CHF} / \mathrm{m}^{2}$. Green roof property owners in Bern receive a $10 \%-50 \%$ reduction in sewage charges resulting in an annual savings of $0.10 \mathrm{CHF} / \mathrm{m}^{2}-0.50$ $\mathrm{CHF} / \mathrm{m}^{2}$ (Schönerman, 2007). An annual savings of $0.45 \mathrm{CHF} / \mathrm{m}^{2}$ was calculated in the NPV cash flow analysis for green properties in Basel, Bern and those with unspecified locations in Switzerland. Currently in the Netherlands no stormwater fee reduces cost or benefits green roof property owners (Jacobs, 2014).

Green roof subsidies in Switzerland were offered for a limited time and initiated widespread green roof construction.Municipalities offering a one-time subsidy for green roof construction vary depending on location. In both Amsterdam (Brouwer, 2014) and Rotterdam (Ravesloot, 2014) the current green roof plan will end in 2014 and this is possibly the time for a new subsidy program.A campaign to increase green roofs in Basel was started in 1996 after it was proven that green roofs provide habitats for regional endangered beetles. The municipality funded $20 \%$ of the initial cost for construction or renovation if homeowners installed green roofs on their property and followed specific design guidelines including use of local substrate and native plant seed mixtures (Brenneisen, 1997). The Canton of Basel 
initiated a test period for green roof designs starting in the mid-1990s with two subsidy programs. This time worked as a test period for architects and distributors to bring down the costs of green roofs and the government mandate came into effect in 2002 with little resistance (Brenneisen, 2010). Minimal resistance to the mandates was achieved through green roof contests, public leaflets, continuous education programs with the Swiss Green Building Council and implementation of a quality standard for green roof suppliers (Mees, 2014). These programs were used to jump start green roof construction and today the subsidy program is no longer in affect. Therefore one-time subsidies for initial construction costs are not considered for the Switzerland NPV calculations in this research.

In the Netherlands, the Green Roof Program is the only official program in the Rotterdam Water Plan. The Green Roof program was implemented in 2008 in the form of a one-time payment of $25 € / \mathrm{m}^{2}$ for all green roof construction. This subsidy was intended to initiate the Green Roof Program and over $120,000 \mathrm{~m}^{2}$ of green roofs have been constructed under the subsidy and over $200,000 \mathrm{~m}^{2}$ have been completed by the end of 2014 . The Green Roof Program was intended to jumpstart the green roof initiative and would ideally lead to a system in which the positive effects of green roofs are promoted by rewarding real estate owners that have green roof installations. For example, this was achieved through a storm water tax reduction for green roof property owners. (Van Roosmalen, 2014). As of 2014 there was a one-time $30 € / \mathrm{m}^{2}$ subsidy for green roof construction. From 2010-2014 the city of Amsterdam imposed a one time subsidy between $€ 25 \mathrm{~m}^{2}$ for small roofs to $€ 50 / \mathrm{m}^{2}$ to the biggest roof (Brouwer, 2014).

\section{Energy Influences}

In 1996 the city of Basel aimed to promote green roofs and better flat roof insulation. During this time over 100 green roofs were planted with a total area of approximately $85,000 \mathrm{~m}^{2}$. The estimated energy savings is 4 million kilowatt hours $(\mathrm{kwH})$ or about 0.5 million liters of heating oil (Mathys, 2007). The energy savings from a green roof cannot be easily generalized considering the many influencing factors. All of the estimations must be site specific in order to consider local energy prices, climate regions and green roof specifications. Several techniques are identified to approximate the total energy savings of a green roof and two are specifically discussed below.

Green roof insulation against temperature fluctuations in the environment results in a lower heat loss in the winter and increased cooling during the summer. As exemplified in a study by Schönerman (2007) an annual savings of $0.5 \mathrm{CHF} / \mathrm{m}^{2}$ per year can be used to estimate reduced energy consumption from a green roof. An annual savings of $0.5 \mathrm{CHF} / \mathrm{m}^{2}$ translates to $0.67 € / \mathrm{m}^{2}$ based on the previously mentioned conversion factor ( $1 \mathrm{CHF}=$ 1.342717 Euros $=0.983495$ USD).

The increased insulation of a green roof is much more effective for old buildings with poor insulation values. However, modern buildings may see hardly any insulation benefits (Beck et al., 2010). This approach would suggest that new buildings built after 2006 will have hardly any added insulation benefit from green roofs. The results include a NPV calculation of green roofs in both countries with no energy savings and including the energy savings approximation to provide a range of values. 
Today, the LCC of extensive green roofs in Switzerland and the Netherlands is less than a conventional flat roof. This research found that an extensive green roof in Switzerland costs between $37 \%$ - 27\% less than a conventional flat roof. In the Netherlands, green roofs were determined to be $16 \%$ - $26 \%$ less than a conventional flat roof. These findings provide confirmation that extensive green roofs in Switzerland and the Netherlands are economically sustainable. Over a 50-year period the calculated mean NPV of extensive green roofs in Switzerland is between $-85.92 € / \mathrm{m}^{2}$ and $-100.65 € / \mathrm{m}^{2}$; a conventional flat roof in Switzerland costs approximately $-137.09 € / \mathrm{m}^{2}$. The calculated mean NPV of green roofs in the Netherlands is between are between $-94.55 € / \mathrm{m}^{2}$ and $-107.93 € / \mathrm{m}^{2}$; a conventional flat black roof costs approximately $-128.18 € / \mathrm{m}^{2}$.

\section{FUTURE OUTLOOK}

The field of construction and property management is rapidly changing along with technology for cost reduction. Green roofs are a building component making them intimately tied with emerging trends in building and construction. The Swiss Chapter of International Facilities Management Association 2011) defines LCC as one component of a whole life costing (WLC) which is an emerging approach to sustainable construction. For example, one major environmental cost consideration for WLC in the construction industry is the reduction of carbon emissions. Building Information Modelling (BIM) has the potential to enable accurate carbon costing and support many other aspects of WLC. According to Caplehorn (2012) the emergence of BIM has the potential to significantly support WLC throughout a building's life cycle by considering maintenance schedules and resolving design issues prior to the construction phase. The United Kingdom government has deemed BIM crucial to its 2025 sustainability goals and will mandate BIM implementation on all federal construction projects no later than 2016. This mandate aims to bring modern green building competence and awareness to the general public (HM Government, 2013; Manning, \& Brew, 2015). With the use of BIM building operators can track LCC data of a building for cost optimization. A BIM can be continuously updated to estimate, track and budget lifecycle costs in regards to a specific building component. This is an example of how facility managers can use BIM to schedule preventative maintenance services and optimize building performance. Autodesk Revit is versatile software developed by Autodesk and is capable of economically evaluating a building over its lifetime (Hore, Kehily, \& Woods, 2014).

Successful green roofs and conventional roofs are not maintenance free and require planned preventative maintenance schedules. For a high quality biodiverse extensive green roof the Swiss Professional Association of Building Greening (SFG) recommends 75\% of the roof area to be covered with at least 20 different indigenous plant species within two years for maintenance purposes. Bare patches that are several square meters must be reseeded. One or two surveys per year should be conducted to keep the gravel strips, roof borders and other roof outlets clear of vegetation (Schmid, 2007). Building Information Modeling facilitates the notification of maintenance schedules, enables maintenance budgeting and improves overall building management with the convenience of a virtual, data rich computer model. 


\section{CONCLUSION}

The Netherlands and Switzerland have different priorities for green roof incentives. Switzerland prioritizes the ecological benefits of green roofs. Major cities such as Zurich and Basel enforced green roof mandates due to the benefit of the natural environment (Green Zurich City, 2014; Mees, 2014). Also, cities like Basel and Bern in Switzerland have developed a technicality in the storm water fees to provide a monetary savings for green roof property owners. These cities mandate green roof installations on all flat, unoccupied new or renovated roofs, which has a noticeable, beneficial effect on the economic costs (Brenneisen, 2010).According to Boer et al. (2013) the city of Rotterdam is leading the way in the Netherlands to develop innovative strategies for water storage and delayed storm water runoff to prepare for the likelihood of climate change. Rotterdam has developed two subsidy programs in the past decade to initiate green roof construction. According to Brouwer (2014) in Amsterdam, green roofs are subsidized in order to improve biodiversity, well-being of people as well as water retention benefits.

Switzerland has a lower NPV for green roofs compared to the Netherlands for two potential reasons. First, green roof construction costs decrease as the roof area increases. Switzerland survey respondents maintained green roof areas that were on average $1450 \%$ larger than survey respondents from the Netherlands.

Secondly, the experienced installation methods of contractors in Switzerland due to green roof mandates has driven down the costs of green roof construction. The green roof mandates in major cities such as Basel and Zurich have seen dramatic drops in green roof costs as a result of increased contractor installation experience (Brenneisen, 2010). The same time effects on green roof construction practices can be predicted in the future for Holland and United States of America where green roofs are limited due to investor uncertainty. A comparison of small roofs (less than $1000 \mathrm{~m}^{2}$ ) shows that the NPV of small green roofs in the Netherlands is $9.2 \%$ less than small green roofs in Switzerland. This shows that the Netherlands has the potential to further decrease costs of green roof construction. This research determined that extensive green roofs in Switzerland and the Netherlands are economically preferable compared to conventional roofs. Additionally, partially accessible,biodiverse extensive green roofs provide optimal environmental benefits as well as many social benefits, making them more sustainable from a holistic viewpoint.

\section{ACKNOWLEDGEMENTS}

Thanks to Stephan Brenneissenand CarstenDruhmann for the mentorship throughout the research process.

\section{LITERATURECITED}

Bau- und Verkehrsdepartement des Kantons Basel-Stadt Tiefbauamt. 2012. Wegleitung über die Abwassergebühren. Basel: Tiefbauamt. [Construction and Transport Department of the Canton of Basel City.2012. Guidelines on the sewage charges. Basel: Civil Engineering.] 
Brenneisen, S. 2007. SFG- Gründach- Label: Hat Qualität in der Dachbegrünung eine Perspektive? [SFG Green roof label: Does quality of green roofs have a perspective?] Hochschule Wädenswil. Wädenswil: Hochschule Wädenswil.

Brenneisen, S. 2009. Ökologisches Ausgleichspotenzial von Extensiven Dachbegrünungen: Bedeutung des Ersatz-Ökotops für den Arten- und Naturschutz und die Stadtentwicklungsplanung [The potential of ecological compensation of extensive green roofs: Importance of compensational ecotopes for species and nature conservation and urban development planning.] (Vol. 41). Basel, Switzerland: Physiogeographica.

Brenneisen, S. 2010. From Pilot to Mainstream: Green roofs in Basel, Switzerland. Wadenswil: Zürcher Hochschule für Angewandte Wissenscafte.

Brenneisen, S. 1997. The Benefits of Biodiversity from Green Roofs - Key Design Consequences. Zurich University of Applied Sciences. Wadenswil: Zürcher Hochschule für Angewandte Wissenscafte.

Brouwer, A. 2014, November 13. Urban Ecologist. (D. Kantor, Interviewer) Amsterdam, Holland.

Caplehorn, P. 2012. Whole Life Costing: A New Approach. London: Routledge.

Castleton, H., V. Stovin, S. Beck, J. Davison. 2010). Green roofs; building energy savings and the potential for retrofit. Energy and Buildings, 42:1582-1591.

CRB Schweizerische Zentralstelle für Baurationalisierung. 2012). LCC Handbuch Instandhaltung und Instandsetzung von Bauwerken. Zürich, Switzerland: CRB Schweizerische Zentralstelle für Baurationalisierung. [CRB Swiss Central Office for Construction Rationalization.2012). LCC Manual of maintenance and restoration of buildings. Zürich, Switzerland: CRB Suisse Center for Rationalization in Construction.]

Dhillon, B. S. 2010. Life Cycle Costing for Engineers. Boca Raton, Florida, U.S.A.: CRC Press.

Green Zurich City. 2014, May 9. Green Roofs. (B. Tschander, Editor) Retrieved November 24, 2014, from Civil Engineering and Waste Department: https://www.stadtzuerich.ch/ted/de/index/gsz/angebote_u_beratung/beratung/ dachbegruenungen.html

Sigrist, H. 2014, December 3. GeschäftsführerDachbegrünungen. [Green Roof Manager]. (D. Kantor, Interviewer)

HM Government. 2013. Industrial Strategy: government and industry in partnership Construction 2025. London: Crown.

Hore, A. V., D. Kehily,T. Woods. 2014. Building Information Modeling for Facility Cost Optimisation: Implications for the QS Profession. Revit Technology Conference Europe 2014. Dublin: Dublin Insitute of Technology.

Jacobs, J. 2014 December 3. Strategic Advisor. Water Department Strategic Advisor. (D. Kantor, Interviewer) Rotterdam, Holland. 
Kaplan, R. 1993. The role of nature in the context of the workplace. Landscape and urban planning, 26 (1):193-201.

Keeler, A., T. Carter. 2008. Life-cycle cost-benefit analysis of extensive vegetated roof systems. Journal of Environmental Management, 87:350-363.

Kellert, S. R. 2008. Dimensions, Elements, and Attributes of Biophilic Design. In S. R. Kellert, J. H. Heerwagen, \& M. L. Mador, Biophilic Design (pp. 3-19). Hoboken, New Jersey, USA: John Wiley \& Sons, Inc.

Manning, R., M. Brew.2015. NBS National BIM Report 2015. New Castle: RIBA Enterprises Ltd 2015.

Mathys, C. 2007. Projektbericht "das bessere Flachdach" 05/06 Basel . Wadenswil: Hochshule Wädenwsil

Mees, H. 2014. Responsible climate change adaptation. Exploring, analysing and evaluating public and private responsibilities for urban adaptation to climate change. Utrecht: Utrecht University.

Ravesloot, C. 2014, November 10. Professor of Applied Sciences at Rotterdam University and INholland University . (D. Kantor, Interviewer)

Sailor, D. J., B. Bass.2014. Development and features of the Green Roof Energy Calculator. Journal of Living Architecture, 1(3):36-58.

Schönerman, S. 2007. Von der Inverstition zur Rendite: Kosten-Nutzen-Rechungen von Dachbegrünungen. [From the investment to positive return: cost-benefit calculations of green roofs.]Wadenswil: Hochshule Gruental.

Schmid, T. 2007. Pflege gut- alles gut? Unterhalt von begrünten Dachflächen. [All's well that ends well? Maintenance of green roofs.] Wädenswil: Hochshule Wädenswil.

Swiss Chapter of International Facilities Management Association. 2011. Life Cycle Costing of Real Estate Part 1: Model. Zürich: IFMA Swizerland.

Ulrich, R. S. 2008. Biophilic Theory and Research for Healthcare Design. In S. R. Kellert, J. H. Heerwagen, \& M. L. Mador, Biophilic Design (pp. 87-106). Hoboken, New Jersey, United States of America: John Wiley \& Sons, Inc.

United States General Services Administration. 2011. The Benefits and Challenges of Green Roofs on Public Buildings. Suitland: United States Genergal Services Administration.

van Peijpe, D., F. Boer, J. Hurtado, J. Jorritsma, E. Marin, A. Wissing, 2013. Rotterdam Adaptation Strategy. Rotterdam, Holland: City of Rotterdam.

Van Roosmalen, P. 2014, September 29. Municipality of Rotterdam Department of Project Management and Engineering, Programme Manager of Green Roofs. (D. Kantor, Interviewer)

Werthmann, C. 2007. Green Roof - A Case Study. New York: Princeton Architectural Press.

Wilson, E. 1984. Biophilia. Cambridge, Massachusetts, USA: Harvard Press University. 